\title{
COMPARATIVE AND COMPETITIVE ADVANTAGE OF JAWA BREBES CATTLE (JABRES) AGRIBUSINESS IN BREBES REGENCY
}

\author{
Suci Nur Utami $\left.{ }^{1}\right) ;$ M. Syaifulloh ${ }^{2)}$ \\ 1)Study Program of Agribusiness Faculty of Sains and Technology, \\ University of Muhadi Setiabudi \\ 2)Study Program of Management Faculty of Economics and Business, \\ University of Muhadi Setiabudi
}

Email: ${ }^{1)}$ id.sucinurutami@gmail.com; ${ }^{2)}$ iman.syaiful7@gmail.com

\section{How to Cite :}

Utami, S.N., M. Syaifulloh, 2019. Comparative and Competitive Advantage Agribusiness of Jawa Brebes Cattle (Jabres) in Brebes Regency. Journal of Agri Socio-Economics and Business. 1 (1): 15-24. DOI: https://doi.org/10.31186/jaseb.1.1.15-24

\section{ARTICLE HISTORY}

Received [xx Month $x x x x]$

Revised [ $x x$ Month $x x x x]$

Accepted [xx Month $x x x x]$

\section{KEYWORDS}

Comparative, competitive, advantage, Jabres cattle,

This is an open access article under the $C C-B Y-S A$ license

\section{ABSTRACT}

The development of Jabres cattle is very important to increase its population in Brebes. TA good development strategy is required to improve Jabres cattle competitiveness. The purpose of this research is to measure the comparative and competitive advantages level of Jabres cattle agribusiness in terms of the value of Domestic Resources Cost Ratio (DRCR) and Private Cost Ratio (PCR), and to determine the priority of Agribusiness of Jabres cattle Agribusiness development strategy by applying the Analytical Hierarchy Process (AHP) method. The results show that the DRCR value is 0.97 and $P C R$ is worth 0.96 . These indicate that Cow Jabres has a comparative and competitive advantage at the national level. Based on the AHP analysis, the most important strategy implemented to develop the agribusiness of Jabres cattle in Brebes is by increased effectiveness in livestock keeping. 


\section{INTRODUCTION}

The livestock sector is one of the important sectors in agricultural development in Indonesia. This sector is beneficial in improving the welfare and food security of livestock farmers. Jabres cattle is one of the local or native cattle in Indonesia which is geographically distributed in Brebes and developed 2012 (Kepmentan, 2012). Jabres cattle belongs to the richness of local genetic resources that need to be protected and preserved.

According to the decree of the Minister of Agriculture number 2842/Kpts/LB. 430/8/2012 concerning the establishment of Jabres cattle clumps, Jabres cattle have characteristics of uniform physical form, able to adapt well in a limited environment, and have a characteristic Distinctive different from other cow clumps. The distinctive characteristic of Jabres cattle is the relatively small body shape, it has no hump, short and pointed horns (Trivena et al., 2011). The average value of Dressing Percentage (DP) Jabres cattle is 51.29 or $2.60 \%$, calving intervals of about $11-14$ months (Aryogi \& Romjali, 2006) and calving intervals of cows Jabres around $18-21$ months (Putro et al ., 2014).

The population of Jabres cattle in 2011 ranged from 23,221 Tails and in Banjarharjo as many as 3,800 tails, which means Jabres cattle population in Banjarharjo is $16.36 \%$ of the total population in Brebes (Putro et al., 2014). The development of Jabres cattle in Indonesia has a high opportunities due to the characteristic characteristic of Jabres cattle which tends to be easy to cultivated. The population of Jabres cattle has increased every year, however the increase is not equivalent to the increase in livestock competitiveness. As a results, local livestock products are unable to compete with imported livestock products. Therefore, the development of Jabres cattle needs to be accomplished with consideration of existing opportunities. The development and competitiveness of Jabres cattle can support the government program in the self-sufficiency of national beef and the development of the Jabres farm center.

Based on above discussion, the problem arises that whether Jabres cattle has a competitive at the national level or not and what is the right strategy in developing Jabres cattle to be more competitive. For that reasons, the purpose of the research is to analyze the competitiveness of Jabres cattle in Brebes and design the strategy of development in Jabres cattle to be more competitive.

\section{RESEARCH METHODS}

\section{Method of Collecting Data}

This survey research was conducted in Banjarharjo district of Brebes. The location is purposively selected with two considerations, namely: 1) Brebes Regency

16 | Suci Nur Utami; M. Syaifulloh; Comparative and Competitiveness Advantages ... 
Government is promoting the development of Jabres cattle so that the population increases, 2) the populations of the Jabres cattle most widely in District of Banjarhajo.

Respondents of this study were 80 Jabres breeder in Banjarharjo District. The data used in this study is the primary data and secondary data. Primary Data is obtained by an interview with a key informant and by distributing the questionnaire to a pre-selected respondent. Secondary data is obtained from data that has been recorded in the institutions related to the research, in this case it is the livestock and animal health service of Brebes and data from the Central Statistical Agency (Maarif \& H. Tanjung, 2003).

\section{Data Analysis Method}

The data analysis used is descriptive analysis and inferential statistics. A descriptive analysis by describing the conditions and characteristics of the Jabres cattle in Brebes. Meanwhile, inferential statistics to analyse the sustainability of the cattle development are using the Policy Analysis Matrix (PAM), a comparative advantage approach (Domestic Resources Cost Ratio (DRCR) and competitive advantages (Private Cost Ratio/PCR) is done to calculate the competitiveness of Jabres cattle in domestic market, as well as Analytical Hierarchy Process (AHP) with Expert Choice program to determine the priority of agribusiness development strategy of Jabres cattle.

\section{Policy Analysis Matrix (PAM)}

The measures performed in the analysis of PAM are 1) determination of input of livestock development of Jabres cattle, 2) classifications inputs into tradable inputs and non tradable inputs, 3) The price determination of the shadow input and the development output of Jabres cattle, 4) Calculation indicators of comparative excellence and competitive development of Jabres cattle.

Table 1. The Policy Analysis Matrix (PAM) Model

\begin{tabular}{lcccc}
\hline \multirow{2}{*}{ Components } & Revenues & \multicolumn{2}{c}{ Costs } & \\
\cline { 3 - 4 } & & $\begin{array}{c}\text { Tradable } \\
\text { Input }\end{array}$ & $\begin{array}{c}\text { Non Tradable } \\
\text { Input }\end{array}$ & Pr \\
\hline Private Price & $\mathrm{A}$ & $\mathrm{B}$ & $\mathrm{C}$ & $\mathrm{D}$ \\
Social Price & $\mathrm{E}$ & $\mathrm{F}$ & $\mathrm{G}$ & $\mathrm{H}$ \\
$\begin{array}{l}\text { Impact of the policy and } \\
\text { market distortion }\end{array}$ & $\mathrm{I}$ & $\mathrm{J}$ & $\mathrm{K}$ & $\mathrm{L}$ \\
\hline
\end{tabular}

Source: Monke and Pearson (1989)

Description of table 1 is $A$ is Private Revenue, $B$ is tradable input private cost, $C$ is non tradable input private cost, $\mathrm{D}$ is profit private, $\mathrm{E}$ is social revenue, $\mathrm{F}$ is tradable input social cost, $\mathrm{G}$ is non tradable input social cost, $\mathrm{H}$ is social profit, I is output transfer, J is transfer of tradable input, $\mathrm{K}$ is transfer factor, and $\mathrm{L}$ is nett transfer. 


\section{Comparative and Competitive Advantages}

Domestic resources Cost Ratio (DRCR) is an indicator of the ability of a commodity system in domestic factor financing at social prices. The assumption is that if the value of DRCR $<1$ means the development of Jabres cattle has a comparative advantage (Panjaitan et al., 2017). The formula of the DRCR calculation is as follows:

$\mathrm{DRCR}=\frac{\mathrm{G}}{(\mathrm{E}-\mathrm{F})}$

Private Cost Ratio (PCR) is an indicator that can determine the number of commodities systems can pay domestic factors and remain in competitive conditions. When the value of $\mathrm{PCR}<1$ means the development of Jabres cattle is said to be able to pay domestic factors on private price and has a competitive advantage. The formula of the PCR calculation is as follows:

$P C R=\frac{C}{(A-B)}$

\section{Analytical Hierarchy Process (AHP)}

The Analytical Hierarchy Process (AHP) is a functional hierarchy with perception as the primary input and aims to solve complex problems in an organized thinking framework that allows it to be applied in making effective decisions (Widiastuti, 2014). The purpose of the application of Analytical Hierarchy Process $(A H P)$ in this research is to determine the right strategy in the development of Jabres cattle in Brebes.

The working principle of Analytical Hierarchy Process (AHP) is to simplify complex problems that are unstructured, strategic, and dynamic into parts and styling in a hierarchy. There are 5 levels of criteria in the AHP structure which is started from focus, factors, actors, objectives, and alternative strategies (Osuna \& Aranda, 2007). The steps in structuring the Analytical Hierarchy Process (AHP) are as follows: (a) determination of the objectives based on the problem, (b) Determination of criteria through Focus Group Discussion (FGD) with the key informant that is competent to determine the strategy of Jabres development. Key informant involved in the study are from academics, business people, government, and society, (c) Alternative determination such as determining the criteria done at the time of discussion with the key informant, (d) Dissemination of questionnaires to key informant, ( $f$ ) Matrix preparation of the average result obtained, and ( $g$ ) Analysis of the results of the Expert Choice to know the value of inconsistencies and priorities (Anggraini et al., 2018). 


\section{RESULTS AND DISCUSSION}

\section{Competitiveness in the development of Jabres cattle}

The competitiveness of Jabres cattle in Brebes is analyzed by the Policy Analysis Matrix (PAM), a comparative advantage approach (Domestic Resources Cost Ratio (DRCR) and competitive advantage (Private Cost Ratio (PCR) to calculate the competitiveness of cattle beef Jabres in the domestic market, as presented in Table 2.

Table 2. Average revenue and components of the cost of development of Jabres cattle in Brebes (Rp/Kg/Period)

\begin{tabular}{|c|c|c|c|c|}
\hline \multirow[b]{2}{*}{ Components } & \multicolumn{2}{|c|}{ Private Price } & \multicolumn{2}{|c|}{ Social Price } \\
\hline & $\begin{array}{l}\text { Tradable } \\
\text { Input }\end{array}$ & $\begin{array}{c}\text { Non } \\
\text { Tradable Input }\end{array}$ & $\begin{array}{l}\text { Tradable } \\
\text { Input }\end{array}$ & $\begin{array}{c}\text { Non } \\
\text { Tradable Input } \\
\end{array}$ \\
\hline \multicolumn{5}{|l|}{ Revenue } \\
\hline - Cattle & & 9.980 .000 & & 10.015 .000 \\
\hline - Carcass & & 980.000 & & 980.000 \\
\hline Total Revenues & & 10.960 .000 & & 10.995 .000 \\
\hline \multicolumn{5}{|l|}{ Costs } \\
\hline 1. Breeder & & 4.267 .989 & & 5.250 .675 \\
\hline 2. Land lease & & 1.980 .789 & & 1.980 .789 \\
\hline \multicolumn{5}{|l|}{ 3. Feed } \\
\hline - Forage & & 527.500 & & 527.500 \\
\hline - Concentrate & & 487.989 & & 487.989 \\
\hline - Vitamin dan Medicine & 9.670 & 168.866 & 10.265 & 168.866 \\
\hline 4. Labor & & 1.977 .890 & & 1.267 .900 \\
\hline 5. Transportation & & 40.000 & & 40.000 \\
\hline 6. Electricity & & 15.000 & & 15.000 \\
\hline 7. Depreciation & & 68.853 & & 68.863 \\
\hline 8. Marketing & & 997.675 & & 895.600 \\
\hline 9. Other costs & & 57.870 & & 60.083 \\
\hline Total Costs & & 10.590 .421 & & 10.763.265 \\
\hline Profit & & 369.579 & & 231.735 \\
\hline
\end{tabular}

Based on private price, total acceptance of breeder in one period of development of Jabres cattle is Rp 10,960,000.00 with total cost of Rp 10,590,421.00 so the profit is $\mathrm{Rp} 369,579,000.00$. While based on social price, total acceptance and total cost is Rp $10,995,000.00$ and $R p 10,763,265,000.00$ so the profit is Rp $231,735.00$. 
Based on Table 2, the value of DRCR is 0.97 informing that to get 1 unit of profit on the development of Jabres cattle in Brebes requires an additional non tradable input of 0.97 at social prices.

The PCR value is obtained by 0.96 informing that to obtain 1 unit of profit on the development of Jabres cattle requires an additional non tradable input of 0.96 at a private price. The value of $\mathrm{DRCR}<1$ means that the development of Jabres cattle has a competitive advantage. The DRCR value higher than the PCR value indicates that no government policy supports the development of Jabres cattle.

Table 3. Policy Analysis Matrix (PAM) in the Development of Jabres Cattle

\begin{tabular}{|c|c|c|c|c|}
\hline \multirow[b]{2}{*}{ Components } & \multirow[b]{2}{*}{ Revenues } & \multicolumn{2}{|c|}{ Cost } & \multirow[b]{2}{*}{ Profit } \\
\hline & & $\begin{array}{l}\text { Tradable } \\
\text { Input }\end{array}$ & $\begin{array}{c}\text { Non-tradable } \\
\text { Input }\end{array}$ & \\
\hline Private Price & 10.960 .000 & 9.670 & 10.590 .421 & 369.579 \\
\hline Social Price & 10.995 .000 & 10.265 & 10.763 .265 & 231.735 \\
\hline Impact of the policy & -35.000 & -595 & -172.844 & 137.844 \\
\hline
\end{tabular}

Table 3 shows that the development of Jabres cattle is profitable in private price as well as social price. This indicates that the existing resources have been efficiently used so that they can compete at the international level. Government policies that distorsif lead to divergences. Supporting instruments have been applied in a policy so that policies can positively impact input and output (Lestari et al., 2017). The impact of government policy is seen in the Policy Analysis Matrix (PAM) table. The Government establishes policies for the purpose of providing protection to producers and consumers. The magnitude of the policy impact can be known from the Output Transfer (OT) indicator, Nominal Protection Coefficient on Output (NPCO), Input Transfer, Factor Transfer, and Nominal Protection Coefficient on Input (NPCl) (Handayani, 2013).

\section{Strategy for Jabres Cattle Agribusiness Development}

The structure of the hierarchy used in formulating the development strategy of Jabres cattle in Brebes consists of 5 levels of hierarchy (Osuna \& Aranda, 2007), namely:

1. The main target to be achieved is "cow cattle development strategy in Brebes District

2. Participants involved in achieving the target are farmers, academics, government, and financing institutions.

3. The factors influencing the achievement of the target is the management, business income, environment, and government policy (Ekowati et al., 2015).

4. Research objectives is to formulate strategies to develop Jabres cattle in Brebes. Livestock development is intended to increase livestock populations, improve 
the welfare of farmers, and increase the competitiveness of Jabres cattle at national and international levels.

5. Alternative strategies gained from the results of Focus Group Discussion (FGD) with all actors involved in the research. Alternative strategies gained include:

a. Improvement of the quality of inputs/feeder to be developed

b. Increase in daily weight gain (PBBH)

c. Improving the effectiveness of maintenance activities with the help of appropriate technology

d. Increased marketing activities

e. Increasing the role of government in supporting development of Jabres cattle

f. Giving access to financial financing easier

g. Improvement of supporting facilities and infrastructure, such as access information that is open to farmers

Table 4. The value of a hierarchy of cattle development

\begin{tabular}{ll}
\hline \multicolumn{1}{c}{ Components } & Values \\
\hline Participants & \\
1. Farmers & 0,277 \\
2. Academics & 0,104 \\
3. Goverments & 0,490 \\
4. Financing Institution & 0,129 \\
\hline
\end{tabular}

\section{Factors}

1. Management

0,201

2. Income

0,124

3. Environment

0,246

4. Government Policy

0,429

Goals

1. Increased in livestock populations

0,395

2. Increased farmers income

0,142

3. Increased livestock competitiveness

0,463

Alternative of strategies

1. Increased livestock production inputs

0,032

2. Increased livestock daily weight

0,086

3. Increased effectiveness in livestock maintenance

0,245

4. Increased Livestock Marketing

0,138

5. Improvement of Government role/support

0,204

6. Increased access to financing for farmers

7. Improvement of support facilities and infrastructure

0,136 


\section{Role of Participants}

According to table 4, it is known that the main priority of development is government with value 0.439 . The next priority is the farmer with a value of $0.277, a$ financial institution with a value of 0.129 and academics with a value of 0.104 . The government has the greatest weight because the government is the main policy makers related to the cattle development strategy in the Jabres cattle in Brebes. The government facilitates the availability of both quantity and quality products in order to meet the established national standards by involving the private sector and farmers who help to realize the quality of livestock products through production, import, processing, marketing, and distribution of products (Mayulu \& Sutrisno, 2010). The role of the government in the development of the farm is as a regulator and insulator who contributed as policy makers and funders for development (Yuniar et al., 2016).

\section{Role of Factors}

The most influential factor in the development of Jabres cattle is the policy of government weighing 0.429. Government-taken policies should be able to cover input, cultivation, and marketing market policies (Mayulu \& Sutrisno, 2010). One of the supporters in the effectiveness of government policy is the motivation of business. Therefore, it is necessary to support the improvement of activities, training, and technical guidance structured for the farmers of Jabres cattle (Widiastuti, 2014).

\section{Role of Goals}

Increased competitiveness of Jabres cattle occupies the most important position in the development of Jabres cattle with a weight of 0.463 . Increased competitiveness is expected to improve the welfare of farmers. The increase in competitiveness will support the national meat self-sufficiency program that has been proclaimed by the government long enough. Competitiveness is not only oriented to the economic sector, but also the readiness and ability of Brebes regency in the face of global competition (Dlbokić, 2017).

\section{Role of Strategies}

1. The priority of the strategy of the Jabres cattle development in order is as follows:

2. Improving the effectiveness of keeping activities with the help of appropriate technology (0.245)

3. Increasing the role of government in supporting the development of Jabres cattle (0.204)

4. Giving access to financial financing easier (0.159)

5. Increased marketing activities (0.138) 
6. Improvement of supporting facilities and infrastructure, such as access to information open to farmers (0.136)

7. Increased daily weight gain (PBBH) Cow cattle Jabres $(0.086)$

8. Improvement of the quality of inputs/feeder cattle to be developed (0.032)

The strategy to increase the keeping efficiency of Jabres cattle was an attempt to support the development of Jabres cattle. Based on the results of the survey, livestock is still traditional and the production is not optimal and has an impact on the lack of farmers income.

The development of Jabres cattle is declared successful when achieved support and good synergy between various parties such as farmers, governments, academics, and financial institutions (Erdil \& Erbıyık, 2015).

\section{CONCLUSIONS AND POLICY IMPLICATIONS}

\section{Conclusions}

The conclusion of this research is the Jabres cattle has a national competitiveness. It is seen from the values of DRCR and PCR $<1$ which means the development of cattle Jabres in Brebes Regency has a comparative and competitive advantage.

The priority of the cattle development strategy is improving the maintenance system to become more technologically appropriate, increase government support, access financial financing more easily, improve marketing, Improve support facilities and infrastructure, such as access information that is open to farmers, increase the daily weight gain livestock, and improve the quality of inputs that will be developed.The successful development of Jabres cattle depends on government support including market input, cultivation, management, and marketing policies that synergize with farmers, academics, and financial institutions.

\section{REFERENCES}

Anggraini, D. C., Bandono, A., Putra, I. N., \& Susanto, A. D. (2018). Implementation of Swot-Ahp Method to Determine the Best Strategy on Development Women Navy Resources in Indonesian War Ship. 2(9), 11-20.

Aryogi, \& Romjali, E. (2006). Pengembangan Sapi Potong Lokal Sebagai. Lokakarya Nasional Pengelolaan Dan Perlindungan Sumber Daya Genetik Di Indonesia 2006, 151-167. Retrieved from 
http://peternakan.litbang.pertanian.go.id/fullteks/lokakarya/lgen0617.pdf?secure $=1$

Dlbokić, M. (2017). SWOT - AHP Model for Prioritization of Strategies for Development of Viticulture in Jablanica District - Serbia. 22(1), 44-52.

Ekowati, T., Prasetyo, E., Setiadi, A., Sumardjono, D., \& D, T. (2015). "Pengembangan Sumber Daya Lokal Dalam Agribisnis Peternakan."

Erdil, A., \& Erbıyık, H. (2015). Selection Strategy via Analytic Hierarchy Process: An Application for a Small Enterprise in Milk Sector. Procedia - Social and Behavioral Sciences, 195, 2618-2628. https://doi.org/10.1016/j.sbspro.2015.06.463

Handayani, S. (2013). Analisis Daya Saing Usaha Peternakan Sapi Potong dan Usaha Budidaya Ikan Patin di Kabupaten Indragiri Hulu Provinsi Riau. Institut Pertanian Bogor.

Kepmentan RI Nomo2 2842/Kpts/LB.430/8/2012 tentang Penetapan Rumpun Sapi Jabres.

Lestari, R. D., Baga, L. M., \& Nurmalina, R. (2017). Daya Saing Usaha Penggemukan Sapi Potong Peternakan Rakyat Di Kabupaten Bojonegoro, Jawa Timur. $\begin{array}{lll}\text { Buletin } \quad \text { Peternakan, } & 101 .\end{array}$ https://doi.org/10.21059/buletinpeternak.v41i1.16906

Maarif, S., \& H. Tanjung. (2003). Teknik-Teknik Kuantitatif untuk Manajemen. Jakarta: PT. Grassindo.

Mayulu, H., \& Sutrisno, C. I. (2010). Kebijakan Pengembangan Peternakan Sapi Potong di Indonesia. Jurnal Penelitian Dan Pengembangan Pertanian, 29(1). https://doi.org/10.21082/jp3.v29n1.2010.p

Osuna, E. E., \& Aranda, A. (2007). Combining SWOT and AHP Techniques For Strategic Planning. Isahp, 1-8.

Panjaitan, M. H., Sihombing, L., \& Kesuma, S. I. (2017). Analisis daya saing dan dampak kebijakan pemerintah terhadap komoditi karet di kecamatan pintu pohan kabupaten toba samosir. 1-13.

Putro, H. O., Setiadi, A., \& Kustiawan, L. (2014). ANALISIS FAKTOR-FAKTOR YANG MEMPENGARUHI DI KABUPATEN BREBES ANALYSIS OF FACTORS AFFECTING BEEF CATTLE BUSINESS DEVELOPMENT JAVA BREBES ( JABRES ) PENDAHULUAN Pengembangan sapi potong di Indonesia khususnya sapi lokal perlu dilakukan untuk memenuhi kebutu. Agromedia, 32(1), 1-11.

Trivena, Budisatria, I. G. S., \& Hartatik, T. (2011). Perubahan Fenotip Sapi Peranakan Ongole, Simpo, dan Limpo pada Keturunan Pertama dan Keturunan Kedua (BackCross). Buletin Peternakan, 33(2), 11-16.

Widiastuti, R. (2014). Strategi Pengembangan Sapi Potong di Kabupaten Gorontalo.

Yuniar, P. S., Fuah, A. M., Studi, P., \& Perencanaan, I. (2016). Analisis Potensi Pengembangan Peternakan Sapi Potong di Kota Tangerang Selatan. Jurnal IImu Produksi Dan Teknologi Hasil Peternakan, 3(2), 106-112. 